\title{
PERILAKU MASYARAKAT SUNDA MUSLIM DALAM MENGONSUMSI PRODUK HALAL DI KOTA BANDUNG
}

\author{
Mulyaningrum \\ mulyaningrum@unpas.ac.id \\ Erik Syawal Alghifari \\ Fakultas Ekonomi dan Bisnis - Universitas Pasundan
}

diterima: 28/12/2017; direvisi: 21/1/2018; diterbitkan: 24/2/2018

\begin{abstract}
This study aims to analyze the relationship between the level of knowledge and behavior of the Sundanese Muslim community in Bandung about halal food and beverage products. The method used in this research is descriptive and verifikatif. The data were collected using questionnaires, completed with observation. Data analysis using validity test, reliability test, linear regression, correlation, hypothesis test, and coefficient of determination. The correlation test result is 0.376 , which shows that it is in the interval $0.20-0.399$, and the coefficient of determination test shows the influence of 0.142. This means that the influence of knowledge level on the behavior of Muslim sunda society is $14.2 \%$. The difference of $85.8 \%$ is the influence of other factors not examined. This figure indicates that the increased knowledge of respondents on halal products will increase the behavior in consuming halal products.
\end{abstract}

Keyword: behavior of the Sundanese Muslim community, halal product

\begin{abstract}
Abstrak
Penelitian ini bertujuan untuk menganalisis tingkat pengetahuan dan perilaku masyarakat Sunda Muslim di Kota Bandung tentang produk makanan dan minuman halal. Metode yang digunakan dalam penelitian ini adalah deskriptif dan verifikatif. Pengumpulan data dilakukan dengan menggunakan kuesioner, dilengkapi dengan observasi. Analisis data menggunakan uji validitas, uji reliabilitas, regresi linier, korelasi, uji hipotesis, dan koefisien determinasi. Hasil uji korelasi bernilai 0,376, yang menunjukan berada di interval 0,20-0,399, dan uji koefisien determinasi menunjukan adanya pengaruh sebesar 0,142 . Artinya, pengaruh tingkat pengetahuan terhadap perilaku masyarakat sunda muslim adalah $14,2 \%$. Selisihnya $85,8 \%$ merupakan pengaruh dari faktor lain yang tidak diteliti. Angka ini mengindikasikan bahwa peningkatan pengetahuan responden atas produk halal akan meningkatkan perilaku dalam mengonsumsi produk halal.
\end{abstract}

Kata Kunci: perilaku masyarakat sunda muslim, produk halal 


\section{PENDAHULUAN}

Berdasarkan statistik, populasi Muslim telah tumbuh signifikan dibanding agama-agama lainnya di dunia. Jumlah penduduk Muslim yang merupakan 23,4 persen dari populasi dunia, diprediksi akan menyentuh 60 persen memasuki tahun 2070. Indonesia adalah negara dengan jumlah penduduk muslim terbesar di dunia. Dalam catatan The Pew Forum on Religion \& Public Life pada 2010, Indonesia disebut sebagai negara dengan populasi Muslim tertinggi. Persentase Muslim Indonesia mencapai hingga 12,7 persen dari populasi dunia. Dari 205 juta penduduk Indonesia, dilaporkan sedikitnya 88,1 persen beragama Islam. (http://khazanah.republika.co.id, 9 Juni 2016).

Penduduk Indonesia yang mayoritas beragama Islam ternyata belum terlindungi dari produk-produk yang tidak halal. Hal ini ditengarai oleh banyaknya peredaran produk makanan dan minuman yang tidak berlabelkan halal. Kondisi ini sangat mengkhawatirkan karena pemerintah bersikap pasif, tidak proaktif dalam menangani permasalahan. Banyak produsen yang tidak mendaftarkan produknya secara resmi, tetapi masyarakat tidak menyadarinya, atau bersikap acuh tak acuh. Hal-hal tersebut menjadi salah satu penyebab lambatnya kesadaran masyarakat atas kehalalan produk yang dipasarkan di Indonesia (Karim, 2013).

Menyadari situasi tersebut maka pemerintah berkewajiban untuk melindungi warga negaranya yang beragama Islam agar tidak mengkonsumsi produk yang diyakini tidak halal. Hal ini merupakan implementasi dari amanat sejumlah peraturan perundangan. Pasal 30 Undang-Undang Nomor 7 tahun 1996 tentang Pangan, mengatur label dan iklan pangan yang menyatakan bahwa: (1) Setiap orang yang memproduksi atau memasukkan pangan ke dalam wilayah Indonesia yang dikemas untuk diperdagangkan, wajib mencantumkan label pada, di dalam, dan atau di kemasan pangan; (2) Label, sebagaimana dimaksud pada ayat (1), memuat sekurang-kurangnya keterangan mengenai: a. nama produk; b. daftar bahan yang digunakan; c. berat bersih atau isi bersih; d. nama dan alamat pihak yang memproduksi atau memasukkan pangan ke dalam wilayah Indonesia; e. keterangan tentang halal; dan f. tanggal, bulan, dan tahun kedaluwarsa (Karim, 2013).

Perilaku masyarakat dalam mengkonsumsi suatu produk akan dipengaruhi oleh kebudayaan sebagai faktor salah satu faktor penting (Karim, 2013). Budaya bahkan menjadi faktor utama dalam perilaku pengambilan keputusan dan perilaku pembelian. Budaya konsumsi yang muncul pada suatu komunitas juga dipengaruhi faktor lain, yaitu strategi pemasaran, serta konsumsi massal yang meningkat sejalan dengan semakin banyaknya orang yang berpendapatan lebih. Oleh karena itu, budaya juga mempunyai berbagai makna dari suatu perilaku konsumsi pada suatu masyarakat (Utami, 2010).
Masyarakat Sunda dalam kehidupan sosialnya cenderung menampilkan nilai-nilai Islam. Masyarakat Sunda mempunyai keyakinan relatif atas apa yang baik dan buruk, yang benar dan salah, yang seharusnya dan yang tidak seharusnya ada dalam perilaku sosialnya. Nilai-nilai yang dipedomani orang Sunda tidak berdiri sendiri, tetapi berkaitan dengan nilai-nilai pandangan hidup menurut agama Islam. Sebagai contoh, nilai sosial seperti: Ajeg dina agama, bermakna taat dan patuh terhadap agama dan berperilaku baik dalam hidup bermasyarakat sesuai tuntunan agama. Adapun agama mayoritas yang dianut oleh masyarakat Sunda yakni Islam. Oleh karena itu secara umum, karakter masyarakat Sunda dilandasi oleh nilai-nilai agama Islam, yang mengacu kepada "citra sebagai insan ahlaqul karimah" yakni keseimbangan antara agama, sosial dan ekonomi (Abdullah, 2006).

Ada perubahan gaya hidup masyarakat Sunda menjadi lebih konsumtif terhadap produk-produk baru dan pergeseran pola konsumsi makanan dari tradisional ke modern. Hal ini didorong oleh munculnya keanekaragaman produk yang tersedia di pasar. Selain itu, kebutuhan akan produk-produk yang sehat dan halal telah menjadi pilihan utama hampir seluruh masyarakat pada saat ini. Adapun pengertian produk halal menurut Majelis Ulama Indonesia (MUI) Jawa Barat adalah produk yang memenuhi syarat kehalalan sesuai dengan syariat Islam. Kehalalan produk menjadi suatu hal yang penting untuk eksistensi produk itu sendiri, demi menjaga kenyamanan para konsumennya.

Perkembangan produk-produk halal semakin tinggi, terutama pada produk makanan, obat-obatan, dan kosmetika. Hal ini mengakibatkan konsumen dihadapkan pada berbagai pilihan produk yang menarik minat untuk mencoba jenis produk baru tersebut. Mengkonsumsi produk halal dan baik (thoyib) merupakan perintah Allah SWT yang wajib dilaksanakan oleh setiap orang yang beragama Islam. Dengan demikian, pilihan untuk mengkonsumsi produk halal dilandasi oleh iman dan taqwa, karena kewaajiban untuk mengikuti perintah Allah SWT. Oleh karena itu, mengkonsumsi produk halal merupakan ibadah yang mendatangkan pahala dan memberikan kebaikan dunia dan akhirat (Shihab, 2000).

Masyarakat Sunda yang mayoritas beragama Islam dan memegang teguh nilai dan normal yang dianutnya. Mereka meyakini bahwa suatu produk akan terjaga kualitas dan asal muasalnya, jika telah mendapat sertifikasi halal. Kota Bandung mempunyai potensi ekonomi yang cukup tinggi sebagai representasi dari masyarakat Sunda. Pada tahun 2014 Penduduk Kota Bandung yang beragama Islam berjumlah 2.509.854 jiwa dari total jumlah penduduk Kota Bandung 2.748.733, sedangkan sisanya beragama Kristen, Khatolik, Hindu Budha, Kong Hucu dan Kepercayaan. (https://bandungkota.bps.go.id, 9 Juni 2016).

Banyaknya jumlah penduduk Muslim dan meningkatnya inovasi berbagai produk telah telah 
menyebabkan semakin tingginya aktifitas ekonomi. Penelitian ini dimaksudkan untuk menganalisis tentang (1) Bagaimana tingkat pengetahuan produk halal masyarakat Sunda Muslim di Kota Bandung (2) Bagaimana perilaku masyarakat Sunda Muslim di Kota Bandung dalam mengkonsumsi produk makanan dan minuman halal (3) Bagaimana pengaruh tingkat pengetahuan tentang produk halal terhadap perilaku masyarakat Sunda Muslim di Kota Bandung dalam mengkonsumsi produk makanan dan minuman.

Karena keterbatasan sumberdaya, maka penelitian ini dibatasi pada perilaku masyarakat Sunda Muslim dalam mengonsumsi produk halal makanan dan minuman di Kota Bandung. Adapun produk makanan dan minuman yang dimaksudkan adalah yang dalam bentuk kemasan, diproduksi oleh pabrikan, serta makanan dan minuman yang disajikan di restoran setempat.

\section{METODE}

Metode yang digunakan dalam penelitian ini adalah deskriptif dan verifikatif. Metode penelitian deskriptif digunakan untuk menggambarkan dan menjelaskan keadaan suatu objek penelitian berdasarkan data yang dikumpulkan kemudian, disusun secara sistematis dan selanjutnya dianalisis untuk diambil kesimpulan. Metode verifikatif digunakan untuk menguji teori dalam menghasilkan informasi ilmiah, yakni status hipotesis, yang berupa kesimpulan sementara.

Metode verifikatif menghasilkan kesimpulan apakah suatu hipotesis diterima atau ditolak. Penelitian ini dimulai dari penentuan variabel-variabel yang dibutuhkan lebih lanjut. Proses ini mencakup identifikasi variabel-variabel dan pengukurannya operasionalnya, penentuan populasi dan sampel yang akan diteliti, pengumpulan dan analisis data, serta menguji hipotesis.

Metode deskriptif dilakukan dengan cara mengumpulkan, menyajikan, serta menganalisis data sehingga memberikan gambaran yang cukup jelas atas obyek yang diteliti untuk dapat ditarik kesimpulan. Dalam penelitian ini metode deskriptif analisis digunakan untuk menjawab pertanyaan pada rumusan masalah sebagai berikut: a) Bagaimana tingkat pengetahuan produk halal masyarakat Sunda Muslim di Kota Bandung; b) Bagaimana perilaku masyarakat Sunda Muslim di Kota Bandung dalam mengkonsumsi produk makanan dan minuman halal.

Metode verifikatif menguji hipotesis dengan menggunakan perhitungan statistik. Dalam penelitian ini metode verifikatif digunakan untuk mengetahui pengaruh tingkat pengetahuan tentang produk halal terhadap perilaku masyarakat Sunda Muslim di Kota Bandung dalam mengkonsumsi makanan dan minuman.

\section{HASIL DAN PEMBAHASAN}

Secara keseluruhan pengetahuan responden tentang produk halal berada pada rentang antara $87 \%-92 \%$. Hal ini menunjukkan bahwa $87 \%$ - 92\% responden mengetahui tentang konsep dasar produk halal seperti: larangan mamakan daging babi, darah, produk yang mengandung organ tubuh manusia, khamer, mengandung unsur najis. Pengetahuan responden dalam aspek produk halal yang mendasar adalah produk yang tidak mengandung babi mencapai 90,5\%; dan produk yang tidak mengandung khamer mencapai 91\%. Hal ini menunjukkan bahwa pengetahuan dasar masyarakat Sunda Muslim terkait kedua indikator tersebut sangat tinggi.

Pengetahuan masyarakat Sunda Muslim kota Bandung menunjukkan tingkat kualitas sangat tinggi, dengan pengertian bahwa tingkat pengetahuan terkait produk halal pada yang diteliti adalah sangat tinggi. Tingkat pengetahuan sangat tinggi ini menunjukkan bahwa masyarakat Sunda Muslim memahami indicatorindikator produk haram terutama pada indikator dasar seperti haram memakan babi, darah, adanya unsur najis, dan mengonsumsi khamer, dan lainnya.

Indikator pengetahuan responden terhadap produk halal yang tertinggi dengan nilai mean 4,38 adalah bahwa produk halal yaitu produk yang tidak mengandung babi. Masyarakat Sunda Muslim di kota Bandung mengetahui bahwa mengonsumsi produk yang mengandung babi hukumnya haram. Hal ini menunjukkan bahwa pengetahuan masyarakat Islam untuk mengonsumsi produk yang tidak halal cukup tinggi. Indikator lain mengenai pengetahuan responden terhadap produk halal yang dinilai sangat tinggi adalah: (1) Tidak mengandung khamer (yang memabukkan); (2) tidak rusak atau kadaluarsa; dan (3) ada label halal. Berdasarkan hasil pengujian dengan statistik $F$ diketahui bahwa ada perbedaan tingkat pengetahuan tentang produk halal yang signifikan berdasarkan pada: (1) Jenis kelamin perempuan dan laki-laki; (2) Karakteristik usia; (3) berstatus pernikahan; (4) Tingkat pendidikan. Meskipun tidak jauh berbeda, data yang terkumpul mengenai tingkat pengetahuan responden terhadap produk halal menurut jenis kelamin, namun terdapat kecenderungan bahwa responden wanita mempunyai tingkat pengetahuan terhadap produk halal yang lebih tinggi dibandingkan responden laki-laki. Gejala ini disebabkan bahwa secara umum responden perempuan lebih banyak berinteraksi dengan makanan dan minuman dalam penyediaan konsumsi produk, sehingga wajar jika mereka memiliki tingkat pengetahuan yang lebih tinggi dibanding dengan lakilaki. Sesuai dengan peran gender, yang diartikan sebagai ide-ide kultural yang menentukan harapan-harapan pada laki-laki dan perempuan dalam berinteraksi antara 
satu dengan lainnya dalam masyarakat. Berangkat dari pengertian tersebut dapat dikemukakan bahwa, peran gender akan selalu mengalami perubahan mengikuti perubahan sosial yang dinamis. Misalnya pada masyarakat tradisional. Pembagian kerja pada masyarakat ini dilakukan berdasarkan jenis kelamin. Pekerjaan laki-laki secara umum ada di sektor publik misalnya mencari nafkah diluar rumah. Sementara pekerjaan perempuan secara umum berada di sektor domestik misalnya, mengurus rumah, menyediakan makanan bagi seluruh anggota keluarga. Hal tersebut senada dengan teori George Peter Murdock dalam Aisyah (2013:208). Dari analisis tersebut dapat disimpulkan bahwa masyarakat Sunda Muslim di Kota Bandung konsisten pada pembagian kerja berdasarkan peran gender antara laki-laki dan perempuan.

Meskipun secara umum pengetahuan terhadap produk halal berdasarkan tingkat pendidikan pada setiap kelompok responden dapat dikatakan tidak memiliki perbedaan yang signifikan, namun jika diperhatikan lebih seksama ada kecenderungan peningkatan yang linear antara pengetahuan responden dengan tingkat pendidikan dari tingkat pendidikan pasca, sarjana, D3, SMA, SMP dan SD.

Budaya Sunda adalah budaya religius sebagai konsekuensi logis dari pandangan hidupnya yang mendasarkan pada ajaran agama Islam. Dalam perspektif ilmu social, agama adalah sistem nilai yang memberikan sejumlah konsep mengenai konstruksi realitas yang berperan besar dalam menjelaskan struktur tata normatif dan tata social, serta memahamkan dan menafsirkan dunia sekitar. Dalam konteks inilah, agama memiliki signifikansinya dalam pengembangan, pembentukan, pengisian, dan pengayaan budaya (Maulana, 2013).

Ajaran agama Islam mudah diterima oleh masyarakat Sunda. Hal ini karena karakteristik agama Islam yang sejalan dengan karakter budaya Sunda. Ada dua hal penting yang menyebabkan agama Islam mudah diterima oleh masyarakat Sunda. Pertama, ajaran Islam sederhana dan mudah dipahami oleh kebudayaaan Sunda, misalnya tentang akidah, ibadah, dan akhlak atau perilaku pada ajaran Islam sangat sesuai dengan jiwa dan karakteristik masyarakat Sunda. Kedua, Agama Islam tidak asing bagi masyarakat Sunda, karena ketika masyarakat Sunda membentuk jati dirinya telah bebarengan dengan proses islamisasi. Oleh sebab itu agama Islam merupakan bagian dari kebudayaan masyarakat Sunda, yang terwujud secara tidak sadar telah menjadi identitas mereka.

Aktifitas keagamaan yang paling banyak memberikan informasi tentang produk halal adalah "mendengarkan ceramah keagamaan di radio dan atau televisi". Jumlah responden yang melakukan aktifitas ini menempati urutan teratas yakni sebanyak $82,5 \%$. Kemudian diikuti oleh "membaca atau mencari informasi terkait produk-produk halal" (makanan dan minuman serta restoran) dalam buku, majalah, brosur, internet dan lainnya sebanyak $81,5 \%$. Selanjutnya "menghadiri pengajian" $81 \%$, "berdiskusi mengenai tema-tema keagamaan" dengan ustadz, kerabat atau keluarga 79,5\% dan "membaca buku ke-Islaman" 79\%. Akses terhadap teknologi informasi dan komunikasi yang semakin tinggi di kota Bandung terbukti telah memberikan kontribusi yang signifikan dalam menyampaikan ajaran Islam, termasuk didalamnya pengetahuan tentang halal dan haram produk makanan dan minuman.

Perilaku masyarakat Sunda Muslim dalam mengonsumsi produk halal dapat dilihat dari beberapa indikator : (1) Seberapa sering mereka memeriksa komposisi bahan/label halal; (2) Mengkonsumsi produk kemasan yang tidak mencantumkan label halal; (3) Makan dan minum di restoran yang tidak bersertifikasi halal; (4) Menggunakan produk kemasan dan makan di restoran yang diragukan kehalalannya; (5) Seberapa sering mereka mendorong, menginformasikan tentang produk halal dan mengajak orang lain untuk tidak menggunakan produk yang tak berlabel halal.

Hasil survey menunjukan bahwa $84,5 \%$ responden sering dan selalu memeriksa komposisi bahan makanan dan minuman sebelum membeli; $83 \%$ responden memperhatikan label halal; $10,5 \%$ yang menyatakan kadang-kadang memperhatikan label halal; dan sisanya ada $6,5 \%$ yang jarang atau tidak pernah memperhatikan adanya label halal pada produk kemasan.

Pada pertanyaan tentang seberapa sering memeriksa komposisi bahan sebelum membeli, masih terdapat responden yang menjawab "kadang-kadang" $10,5 \%$, dan "tidak pernah" $6,5 \%$. Hal ini diduga karena beberapa hal yaitu : (1) Minimnya label halal yang terdapat pada kemasan produk; (2) Sebagian masyarakat Sunda berada di suatu lingkungan dengan keyakinan dan agama yang beragam; (3) Produk-produk yang dibeli pada umumnya diyakini oleh mereka tidak berkaitan dengan hal-hal yang mengubah status kehalalan tersebut, seperti: permen, tahu, tempe, ikan dll.

Untuk mengatasi minimnya label halal pada setiap produk kemasan, perlu ketegasan dari pemerintah untuk mewajibkan semua produsen makanan dan minuman wajib mencantumkan komposisi bahan baku dan bahan olahan dari produk akhir, yang dimaksudkan untuk melihat konten kehalalan produk sebagai persyaratan dalam mengajukan perizinan. Selain itu implementasi dari Undang-Undang No. 8 Tahun 2009 tentang Perlindungan Konsumen perlu dikontrol oleh pemerintah agar tidak merugikan konsumen, terutama produk-produk makanan dan minuman yang di impor dari Negara-negara Non Muslim. Demikan pula halnya dengan pengawasan pada produk lokal yang menggunakan bahan baku impor.

Hampir semua responden mengetahui kriteria kehalalan suatu produk dan meyakini pentingnya memilih produk berlabel halal. Kenyataan menunjukkan adanya degradasi intensitas dalam menerapkan keyakinan tersebut dalam perilaku, yang tercermin 
dalam perilaku sehari-hari dalam mengkonsumsi makanan dan minuman. Hal ini ditunjukkan dengan kenyataan di lapangan bahwa hanya $62,5 \%$ responden yang menyatakan tidak pernah/jarang mengonsumsi produk kemasan yang tidak ada label halal, dan hanya $66 \%$ responden yang menyatakan tidak pernah atau jarang makan di restoran/warung makan yang tidak memiliki sertifikasi halal.

Meskipun mayoritas responden menyatakan bahwa mereka sangat jarang atau tidak pernah mengonsumsi produk yang tidak berlabel halal, namun data lapangan meunjukkan ada sebagian kecil, hanya $15 \%$, responden mengaku sering atau bahkan selalu mengonsumsi produk "tanpa berlabel halal". Terdapat $15 \%$ responden yang sering atau selalu makan di restoran/rumah makan yang "tidak memiliki sertifikasi halal". Hal ini mengindikasikan bahwa ada kecenderungan pada sebagian kecil masyarakat Sunda Muslim yang tidak memperdulikan halal atau tidaknya suatu produk. Hal ini diduga karena alasan berikut : (1) Produk kemasan yang berlabel halal dan rumah makan/ restoran yang telah memiliki sertifikat halal masih sedikit; (2) Sebagian masyarakat Sunda berada di suatu lingkungan dengan keyakinan dan agama yang beragam; (3) Sebagian masyarakat Sunda meragukan apakah produk-produk yang dibeli tidak mengandung bahan-bahan yang tidak halal. Berdasarkan alasan tersebut pada umumnya masyarakat Sunda meyakini bahwa produk kemasan yang tidak berlabel halal dianggap sebagai produk yang halal. Untuk produk makanan dan minuman yang dikonsumsi di restoran/rumah makan juga diyakini terjamin kehalalannya. Hal ini berarti bahwa masyarakat Sunda Muslim di kota Bandung masih kurang kritis untuk produk restoran. Artinya, untuk produk-produk tersebut masih rawan masuknya bahan-bahan yang tidak halal.

Indikator utama yang dinilai penting/sangat penting dan sering menjadi pedoman perilaku Masyarakat Sunda Muslim Kota Bandung saat memutuskan membeli produk kemasan dan makan di restoran/ rumah makan adalah: (1) Merek/Nama restoran yang mencerminkan kehalalan produk; (2) Harga yang merupakan cerminan kualitas produk; (3) Lokasi strategis dari toko/restoran/rumah makan, karena kota Bandung sebagai salah satu destinasi wisata kuliner nasional dan internasional.

Bila dirinci lebih jauh, hasil survey mencatat bahwa $75 \%-82 \%$ responden menilai penting dan sangat penting terkait aspek pemasaran produk makanan dan minuman, seperti: (1) Rasa, (2) Harga, (3) Merek, (4) Kebersihan dan lokasi restoran. Terkait aspek keagamaan seperti tulisan, simbol keislaman, label sertifikasi halal dari suatu produk dinilai penting/sangat penting, dan sering dipertimbangkan oleh responden sebesar $78 \%$. Demikian pula halnya dengan nama toko atau restoran yang menjual produk makanan dan minuman tersebut.
Hal yang menarik adalah penilaian responden terkait pentingnya sertifikasi halal MUI, hanya $75 \%$ responden yang menjawab penting/sangat penting. Padahal indikator ini yang paling tinggi diyakini oleh responden. Hal ini sangat dimungkinkan mengingat bahwa masih sangat sedikit produk makanan dan minuman baik yang dalam kemasan maupun yang dikonsumsi di restoran yang memiliki sertifikasi halal. Oleh karena itu pilihan masyarakat Sunda Muslim selanjutnya beralih kepada indikator yang lain yaitu: (1) Izin dari BPOM, (2) Identitas pemilik toko/restoran, (3) Simbol keislaman.

Berdasarkan analisis tabulasi silang terlihat jelas bahwa hanya $65 \%$ responden konsisten untuk meninggalkan produk yang meragukan, baik produk kemasan maupun restoran yang diragukan kehalalannya. Sementara yang lain terpaksa mengonsumsinya dikarenakan situasi tertentu antara lain sulit untuk mendapatkan produk yang berlabel/ restoran yang bersertifikat halal. Sulitnya untuk mendapatkan produk kemasan berlabel/restoran bersertifikat halal ini ditunjukkan oleh hasil survey yang mencatat hanya $76 \%$ responden menilai mudah atau sangat mudah mencari restoran yang diyakini kehalalannya.

Tingkat kesadaran masyarakat dalam bentuk mendorong, menginformasikan produk halal kepada keluarga/teman serta mencegah mereka untuk tidak mengonsumsi produk tidak halal adalah 79,5\%. Hal ini berarti bahwa $79,5 \%$ yang aktif atau peduli terhadap produk halal dan mencegah dan memberitahukan kepada keluarga agar tidak mengkonsumsi produk tidak halal. Selanjutnya tingkat kesadaran masyarakat dalam bentuk mendorong, memberitahu keluarga/teman dekat untuk tidak makan/ minum yang disajikan rumah makan/restoran yang menjual produk yang tidak halal, memberitahu keluarga/teman dekat tempat/restoran/ warung/rumah makan yang terjamin kehalalan produknya, menunjukkan tingkat yang tergolong tinggi pula yaitu ada dalam rentang $82,5 \%$.

Kota Bandung merupakan kota yang terbuka untuk semua etnis, sehingga melunturkan budaya Sunda Muslim yang sangat fanatik terhadap keislaman, dalam hal ini makanan dan minuman. Padahal dalam mendapatkan produk halal tergolong mudah. Dalam hal pencegahan masih sangat bagus, tetapi dalam implementasi ada unsur yang mengganggu konsistensi perilaku masyarakat, karena Kota Bandung sangat terbuka untuk etnis-etnis lainnya.

Perilaku masyarakat Sunda Muslim signifikan dipengaruhi oleh tingkat pengetahuan produk halal. Hal ini ditunjukan oleh nilai t statistik sebesar 5,717 dan nilai $F$ statistic sebesar 32,680 yang mempunyai tingkat signifikansi $0,000<0,05$. Pengetahuan terkait aspek dasar produk halal diukur menggunakan 13 indikator pengetahuan yang membentuk tingkat pemahaman dasar tentang produk halal, dasar pemahaman ini berpengaruh ke perilaku masyarakat Sunda Muslim (Ekajati, 2009). 
Berdasarkan hasil analisis korelasi dan determinasi, hubungan tingkat pengetahuan tentang produk halal terhadap perilaku masyarakat sebesar 0,376 , berada di tingkat hubungan positif tapi masih rendah. Peningkatan pengetahuan responden atas produk halal, semakin meningkatkan perilaku yang baik dalam mengonsumsi produk halal. Besarnya pengaruh tingkat pengetahuan tentang produk halal terhadap perilaku masyarakat sebesar $14,2 \%$; dan sisanya $85,8 \%$ dipengaruhi oleh faktor lainnya. Berdasarkan hasil yang diperoleh dapat diketahui bahwa tingkat pengetahuan mempunyai pengaruh yang rendah. Hal ini disebabkan adanya pengaruh lain, seperti persepsi masyarakat, lingkungan, dan lainnya (Fahmi, 2011).

\section{KESIMPULAN}

Berdasarkan hasil penelitian dapat diambil kesimpulan sebagai berikut: 1) Pengetahuan masyarakat Sunda Muslim di Kota Bandung menunjukkan tingkat kualitas yang sangat tinggi. Sangat tingginya pengetahuan tersebut menunjukkan bahwa masyarakat Sunda Muslim sangat memahami indikator-indikator produk haram terutama terkait dengan indikator dasar seperti haram memakan babi, darah, adanya unsur najis, mengonsumsi khamer, dan sejenisnya; 2) Perilaku masyarakat Sunda Muslim di Kota Bandung dalam mengkonsumsi produk halal dapat dilihat dari beberapa indicator berikut : (a) Seberapa sering mereka memeriksa komposisi bahan/ label halal, pada indikator ini hampir seluruh responden menjawab sering; (b) Mengonsumsi produk kemasan yang tidak mencantumkan label halal, pada indikator ini hampir seluruh responden menjawab jarang; (c) Makan dan minum di restoran yang tidak bersertifikasi halal, pada indikator ini hampir seluruh responden menjawab jarang; (d) Menggunakan produk kemasan dan makan di restoran yang diragukan kehalalannya, pada indikator ini hampir seluruh responden menjawab jarang; (e) Seberapa sering mereka mendorong, menginformasikan tentang produk halal dan mengajak orang lain untuk tidak menggunakan produk yang tak berlabel halal, pada indikator ini hampir seluruh responden menjawab sering; 3) Perilaku masyarakat Sunda Muslim di Kota Bandung secara signifikan dipengaruhi oleh tingkat pengetahuan tentang produk halal. Pengetahuan telah berkontribusi dalam membentuk tingkat pemahaman dasar bagi masyarakat Sunda Muslim tentang produk halal (Kasmawati, 2014). Dasar pemahaman ini berpengaruh terhadap perilaku masyarakat Sunda Muslim.

\section{DAFTAR PUSTAKA}

Abdullah, A. 2006. Islamic Studies. Yogyakarta: Pustaka Pelajar.

Aisyah, N. 2013. Relasi Gender Dalam Institusi

Alma, B. 2011. Manajemen Pemasaran dan Pemasaran Jasa, Edisi Revisi, Alfabeta, Bandung

Ekadjati, E.S. 2009. Kebudayaan Sunda Suatu Pendekatan Sejarah jilid 1. Jakarta : PT Dunia Pustaka Jaya.

Fahmi, I. 2011. Manajemen Pengambilan Keputusan. Cetakan Kesatu, Alfabeta: Bandung.

Kasmawati, 2014. Makanan Halal dan Thayyib dalam PerspektifAl-Qur'an. Skripsi. Fakultas Ushuluddin, Filsafat dan Politik. UIN Alauddin, Makassar.

Karim, M.A. (2013). Perilaku Komunitas Muslim Perkotaan Dalam Mengonsumsi Produk Halal. Jakarta: Puslitbang Kehidupan Keagamaan Kemetrian Agama RI

Keluarga (Pandangan Teori Sosial Dan Feminis). Muwâzâh, Volume 5, Nomor 2, halaman : 203-224.

Maulana, M. 2013. "Upacara Daur Hidup dalam Pernikahan Adat Sund". Refeksi, Volume 13, Nomor 5, Oktober Shihab, M.Q. (2000). Wawasan AlQur'an. Bandung : Mizan.

Utami, C.W. 2010. Manajemen Ritel: Strategi Dan Implementasi Operasional Bisnis Ritel Modern Di Indonesia, Edisi Kedua. Jakarta : Salemba Empat. http://khazanah.republika.co.id, 9 Juni 2016 